\title{
温間テンプフォーミング処理を施した超微細粒鋼の疲労特性*
}

\author{
長島伸夫 ${ }^{* 1}$ ，古谷佳之 ${ }^{* 1}$ ，木村勇次 ${ }^{* 2}$, 井上忠信 ${ }^{* 1}$
}

\section{Fatigue Properties of an Ultrafine-Grained Steel Processed by Warm Tempforming}

\author{
Nobuo NAGASHIMA*1, Yoshiyuki FURUYA, Yuuji KIMURA and Tadanobu INOUE \\ ${ }^{* 1}$ National Institute for Materials Science, 1-2-1 Sengen, Tsukuba, Ibaraki 305-0047 Japan
}

Giga-cycle fatigue properties were investigated for an ultrafine-grained steel processed by warm tempforming. The fatigue properties of the tempformed (TF) steel were compared with conventional tempered martensite (QT) steel. Fatigue tests were carried out at frequencies of $20 \mathrm{~Hz}$ and $20 \mathrm{kHz}$, using servo-hydraulic and ultrasonic fatigue testing machines, respectively. Both theTF and the QT steels showed surface fracture in short life regions and fish-eye fracture in long life regions. The fish-eye fracture origins were oxide inclusions comprised of $\mathrm{Si}, \mathrm{Mg}, \mathrm{Ca}$ other than $\mathrm{Al}$. Difference of fatigue strength was not notable between the TF and the QT steels, i.e. the fatigue strength of the TF steel was the same as that of the QT steel.

Key Words : Ultrafine-Grained Steel, Warm Tempformig, Giga-Cycle Fatigue, Fish-Eye Fracture, Inclusion

\section{1. 緒言}

温間テンプフォーミング（以下 TF とする）処理を施した鋼は微細なフェライト結晶粒が圧延方向に伸張した 繊維状組織を有し，1500MPa 以上の引張強度でも優れた勒性 ${ }^{(1)(2)}$ を示す. TF 鋼のシャルピー衝撃試験および静的 3 点曲げ試験後の試験片の様相は, 荷重方向とほぼ垂直にき裂が分岐する Crack-arrester タイプの層状破壞（デラ ミネーション）が生じ，勒性の向上はその破壊形態に起因することがわかっている．その上，1500MPaの引張強 度で， TF 処理した $0.6 \% \mathrm{C}-2 \% \mathrm{Si}-1 \% \mathrm{Cr}$ 鋼は焼入れ焼戻し鋼に比べ優れた遅れ破壊特性を有する ${ }^{(3)}$. このような超 微細繊維状フェライト結晶粒組織を有する高強度鋼がどのような疲労特性を示すのかは興味深い. また，高強度 鋼では内部破壊による疲労限の消滅が生じるため, ギガサイクル域までの疲労特性調査が必要となる.

そこで, 本研究では, TF 処理した $0.6 \% \mathrm{C}-2 \% \mathrm{Si}-1 \% \mathrm{Cr}$ 鋼(3) についてギガサイクル域までの疲労特性を調べた.

\section{2. 実験方法}

供試材は過去の研究 ${ }^{(1),(3)}$ で使用したものと同一であり，P，S，O などの不純物元素を 10ppm 以下に抑えた高純 度の鋼（C:0.57, Si:1.96, Mn:0.16, Al:0.041, Cr: 1.02, N: 0.0018 (mass\%)）である．また，温間テンプフォーミング処 理は焼戻しマルテンサイト組織に加工を施すという加工熱処理(1)であり, 供試材の作製工程の概要は以下の通り である ${ }^{(3)}$.まず, $100 \mathrm{~kg}$ 真空溶解, 熱間鍛造・圧延の工程で得た材料から切り出した $4 \times 4 \times 12 \mathrm{~cm}$ のブロックに $1473 \mathrm{~K}$ で $1 \mathrm{~h}$ の溶体化処理, 累積減面率で 55\%の熱間溝ロール圧延を施した後, 油冷してマルテンサイト組織を得た. ついで, マルテンサイト鋼材を $773 \mathrm{~K}$ で $1 \mathrm{~h}$ の焼戻し処理後, 溝ロール圧延により累積减面率 $76 \%$ の温間多パス圧 延を行い, 空冷した. この材料を $\mathrm{TF}$ 材と呼ぶ. サンプルはパス毎に圧延方向廻りに $90^{\circ}$ 回転させ, 圧延工程中

\footnotetext{
* 原稿受付 2012 年 1 月 18 日

*1 正員, (独)物質・材料研究機構（†305-0047 茨城県つくば市千現 1-2-1）

*2 (独)物質・材料研究機構（广305-0047 茨城県つくば市千現 1-2-1）

E-mail: NAGASHIMA.Nobuo@nims.go.jp
} 
の温度をコントロールするため 2 回のパスごとに $773 \mathrm{~K}$ に 5 分間再加熱した。また，最後の 2 パスはサンプルの 断面形状を調整するために同じ孔型に 2 回通過させた. したがって，パススケジュールは2-2-2-3である. 比較と して, TF 処理材を $1123 \mathrm{~K}$ で $10 \mathrm{~min}$ 焼準した後, $1153 \mathrm{~K}$ で $30 \mathrm{~min}$ のオーステナイト化処理・油焼入れ，773K で $1 \mathrm{~h}$ 焼戻処理・水冷した材料（以下 QT 材）を用意した。これらの材料に対して圧延方向を RD とし，最終パスでの 荷重方向（最終圧下方向）を ND とし， RD，ND と垂直な方向を TD と定義した. これらの材料の機械的性質を 表 1 に示す.引張強度は $\mathrm{TF}$ 材, QT 材ともに $1500 \mathrm{MPa}$ 程度であるが，降伏強度や全伸びは $\mathrm{TF}$ 材が大きくなって いる(3).

本供試材の光学顕微鏡組織を図 1 に示す. TF 材は溝ロール圧延により焼戻しマルテンサイト組織を圧延した ため, RD に伸長した超微細繊維状結晶組織となる. 表 2 は, 透過型電子顕微鏡法, 走査電子顕微鏡法, 電子 線後方散乱解析像法による組織解析結果と X 線回折法で計測した転位密度を示す ${ }^{(3)}$. 両材において，結晶方位差 角が $10^{\circ}$ 以上の大角粒界（HAB）の割合はほとんど同じであったが，これらの HAB に関する RDおよび TD の 平均切片長さ $\left(L_{R D}, L_{T D}\right)$ は, QT 材ではそれぞれ $0.49 \mu \mathrm{m}, 0.46 \mu \mathrm{m}$ と大きな差はないのに対し, TF 材では $0.89 \mu \mathrm{m}$, $0.29 \mu \mathrm{m}$ とフェライト粒が RD に伸長した組織となった。 なお, QT 材の平均切片長さは, マルテンサイト組織の 強度・靸性に対する有効結晶粒径であるブロックの大きさを反映する．また，表 2 には示していないが特定の

Table 1 Mechanical properties of the QT and the TF samples.

\begin{tabular}{|c|c|c|c|c|}
\hline Samples & $\begin{array}{c}\text { Yield Strength } \\
\sigma_{0.2}(\mathrm{MPa})\end{array}$ & $\begin{array}{c}\text { Tensile Strength } \\
\sigma_{B}(\mathrm{MPa})\end{array}$ & $\begin{array}{c}\text { Total Elongation } \\
(\%)\end{array}$ & Vickers Hardness \\
\hline QT & 1378 & 1575 & 10.3 & 460 \\
\hline TF & 1464 & 1540 & 12.7 & 439 \\
\hline
\end{tabular}

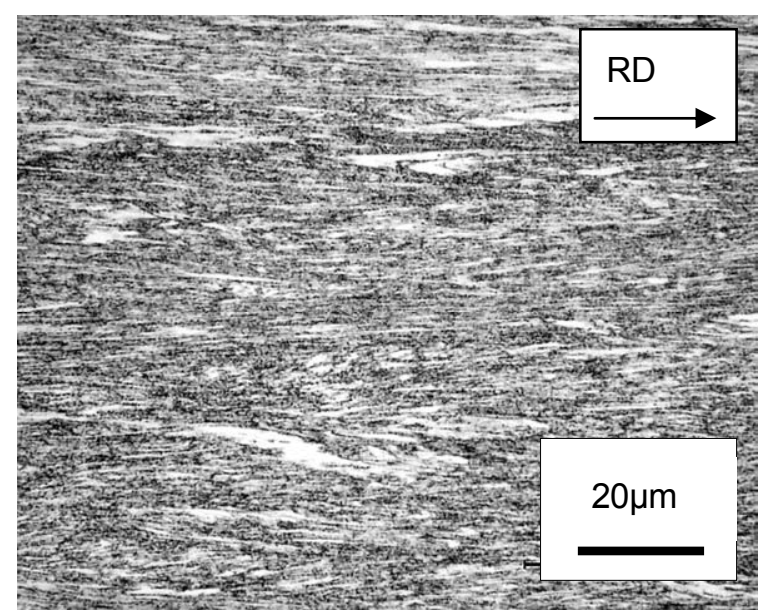

(a) TF sample

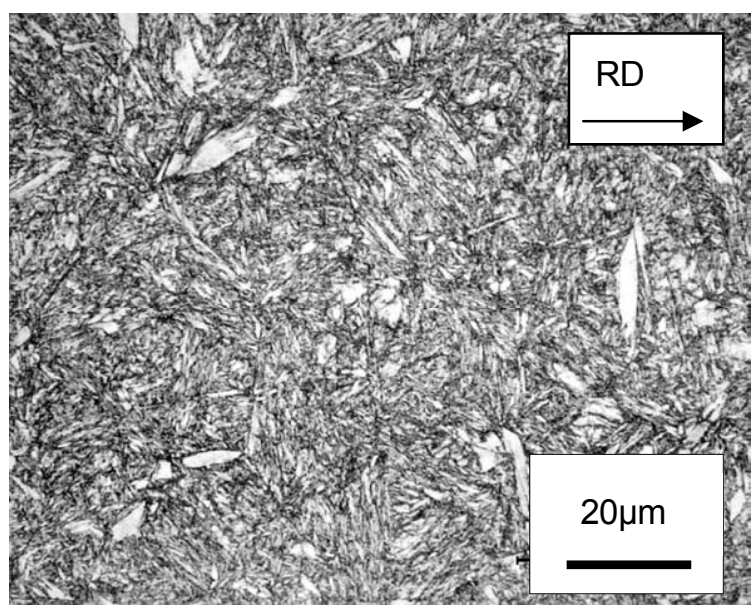

(b) QT sample

Fig.1 Optical microstructures of the TF and the QT samples.

Table 2 Microstructural factors for the QT and the TF samples ${ }^{(3)}$; Average prior-austenite grain size $\left(D_{\gamma}\right)$, average intercept length for the $\mathrm{HAB}(L)$, number fraction of the $\mathrm{HAB}$, dislocation density, and average lengths of the long-axis of the carbide particles.

\begin{tabular}{|c|c|c|c|c|c|c|c|}
\hline \multirow[t]{2}{*}{ Samples } & \multirow[t]{2}{*}{$\begin{array}{c}D_{\gamma} \\
(\mu \mathrm{m})\end{array}$} & \multicolumn{2}{|c|}{$\begin{array}{c}\text { Intercept length for } \\
\operatorname{HAB}\left(\theta>10^{\circ}\right) \\
\qquad L(\mu \mathrm{m})\end{array}$} & \multirow{2}{*}{$\begin{array}{c}\text { Number } \\
\text { fraction of } \\
\text { HAB } \\
(\%)\end{array}$} & \multirow{2}{*}{$\begin{array}{c}\text { Dislocation } \\
\text { density } \\
\rho \\
\left(\mathrm{m}^{-2}\right)\end{array}$} & \multicolumn{2}{|c|}{$\begin{array}{l}\text { Average lengths of the long-axis } \\
\text { of the carbide particles } \\
\text { (nm) }\end{array}$} \\
\hline & & $L_{R D}$ & $L_{T D}$ & & & Transgranular & Intergranular \\
\hline QT & 18 & 0.49 & 0.46 & 87 & $4.6 \times 10^{14}$ & 27 & 92 \\
\hline $\mathrm{TF}$ & - & 0.89 & 0.29 & 80 & $4.7 \times 10^{14}$ & 20 & 97 \\
\hline
\end{tabular}


優先方位を示さない QT 材に比べ TF 材は $<110>/ / \mathrm{RD}$ の加工集合組織（ $\alpha$ ファイバー）を有していた. 転位密度, 炭化物のサイズと分散状態は, ほぼ同等であった. すなわち, TF 材と QT 材はともに結晶粒径が $1 \mu \mathrm{m}$ の以下の 超微細粒組織に炭化物が分散した複相組織を有するが，TF 材と QT 材には結晶粒の形状と集合組織に大きな違 いがある.

疲労試験片採取方向は，両材とも試験片長手方向を RD 方向から採取した．疲労試験は，主に表面破壊となる 高応力・低寿命域を油圧サ一ボ式疲労試験機により繰り返し速度 $20 \mathrm{~Hz}$ で実施し, 主に内部破壊となる低応力・ 長寿命域を超音波疲労試験機により $20 \mathrm{kHz}$ で実施した．超音波疲労試験は繰り返し速度が極端に速いが，内部破 壞では妥当な結果が得られることが過去の研究で明らかになっている( ${ }^{(4)}$. また, 超音波疲労試験の場合には試験 片の発熱を抑えるために冷風（約 $5^{\circ} \mathrm{C}$ ）を吹き付けて試験片を空冷すると同時に，必要に応じて間欠試験も行っ た．試験片形状は共通とし，最小部直径が $3 \mathrm{~mm}$ ，試験部の $\mathrm{R}$ が $31 \mathrm{~mm}$ の砂時計型で試験部の最終仕上げは軸方 向に 1200 番のペーパー仕上げとした. これらの疲労試験は室温大気中, 応力比 $R=-1$ で実施した. 疲労試験後の 破面は光学顕微鏡と電解放射型走查電子顕微鏡（FE-SEM）を用いて観察し，内部破壊の場合には，起点となっ た介在物の構成元素を FE-SEM に付属しているエネルギー分散型X線分析装置（EDX）で分析した.

\section{3. 実験結果と考察}

疲労試験結果を図 2 に示寸．図中オープンマークが油圧サーボ試験機による結果，ソリッドマークが超音波疲 労試験機による結果である. 内部破壊した結果にはダッシュマーク（入）を付している．後述する破面観察に示 寸通り，内部破壞の起点は全て酸化物系の介在物である. 超音波疲労試験の際，QT 材は空冷のみの連続試験が 可能であったが，TF 材は発熱が生じたため, 間欠試験を実施した. 油圧サーボ試験による高応力側の疲労試験結 果は，TF 材では全て表面破壞であるのに対し，QT 材では $\sigma_{a}=900 \mathrm{MPa}$ で破断した試験は 2 本とも内部破壞であ る.これは, QT 材の方で引張強度が若干高いためと考えられる. 超音波疲労試験による低応力側の疲労試験結 果は, QT 材では $\sigma_{a}=850 \mathrm{MPa}$ および $825 \mathrm{MPa}$ で内部破壊し, $800 \mathrm{MPa}$ と $700 \mathrm{MPa}$ で一本ずつの試験片が $10^{10}$ 回で 未破断となった. TF 材では $\sigma_{a}=825 \mathrm{MPa}$ および $800 \mathrm{MPa}$ で一本ずつの試験片が内部破壊し，850MPa と $750 \mathrm{MPa}$ で一本ずつの試験片が $10^{10}$ 回で未破断となった. これらの結果は, $\mathrm{TF}$ 材と $\mathrm{QT}$ 材の疲労強度が同等であることを 示している.

図 3 に QT 材の油圧サーボ試験で内部破壊した破面の起点付近の様相を示寸．同図は $3.56 \times 10^{5}$ 回で破断した試 験片の起点部を拡大したマッチング写真である. 起点となった介在物の大半は破面の片方に付着しており，他方 には介在物が抜け落ちた穴と残存した介在物の一部が残っている. 起点となった介在物の寸法は $20 \mu \mathrm{m}$ 程度で, $\mathrm{EDX}$ 分析では $\mathrm{Al}$ の他に $\mathrm{Si}, \mathrm{Mg}, \mathrm{Ca}$ が検出された. 従って, $\mathrm{Al}$ を主成分とする典型的な酸化物系介在物である.

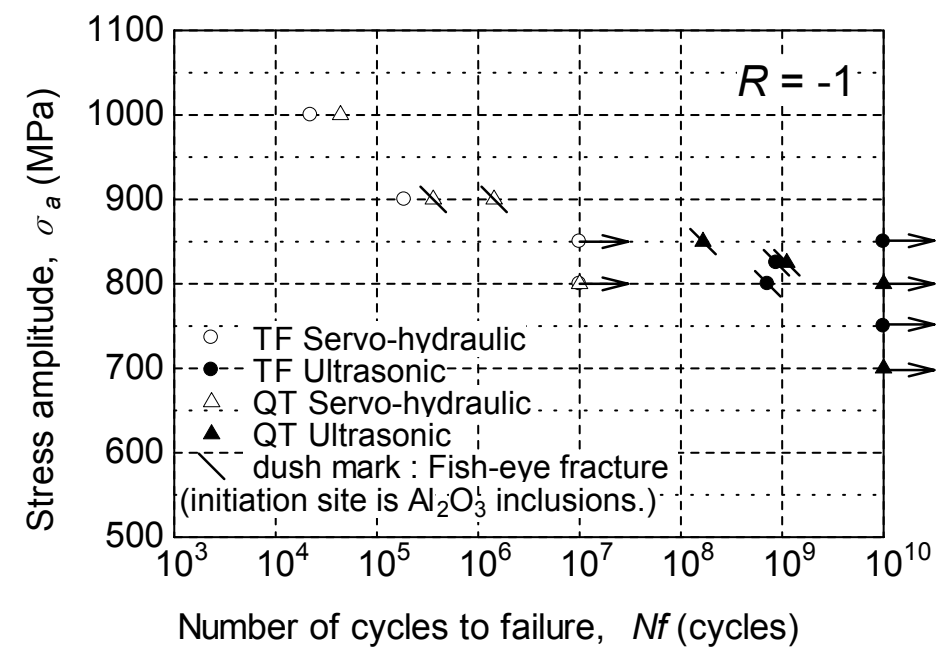

Fig.2 $S$ - $N$ diagrams of the TF and the QT samples. 


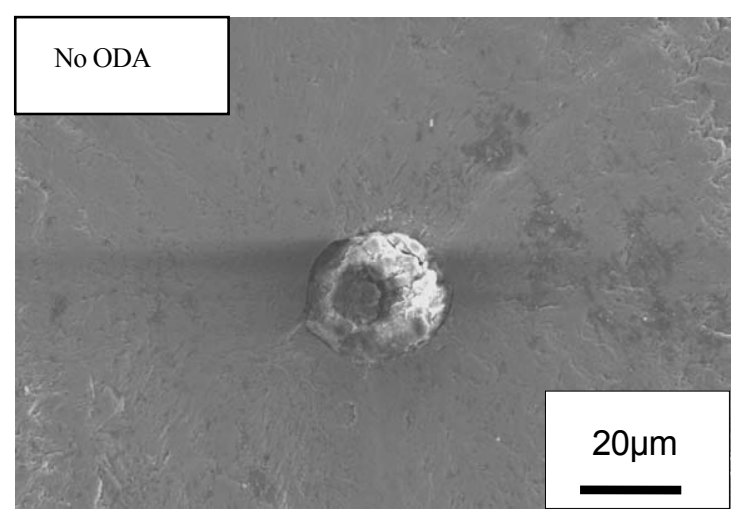

(a) One side

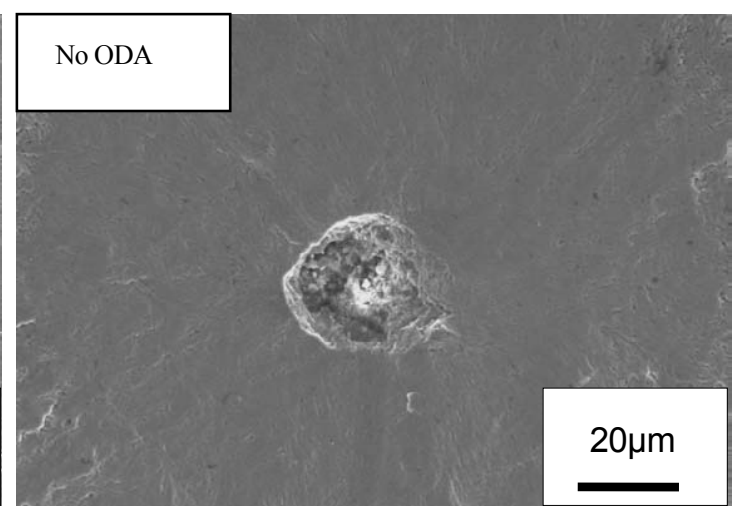

(b) The other side

Fig.3 Fractographs of a QT sample ended in fish-eye fracture. (Servo-hydraulic, $\sigma_{a}=900 \mathrm{MPa}, N_{\mathrm{f}}=3.56 \times 10^{5}$ cycles)

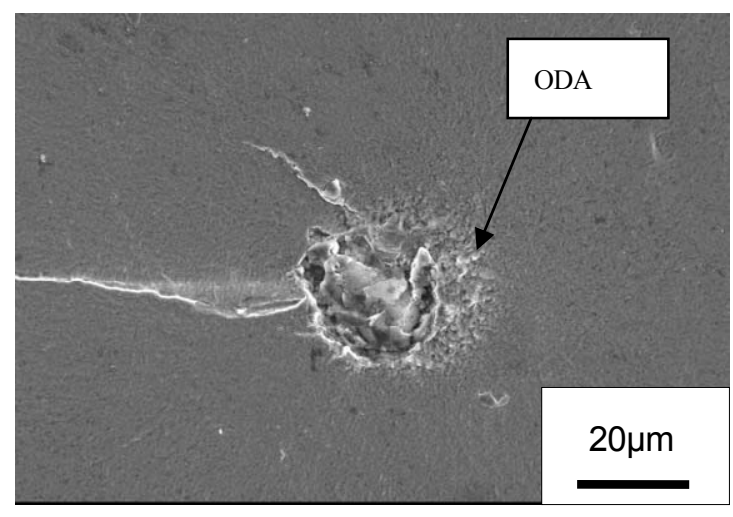

(a) One side

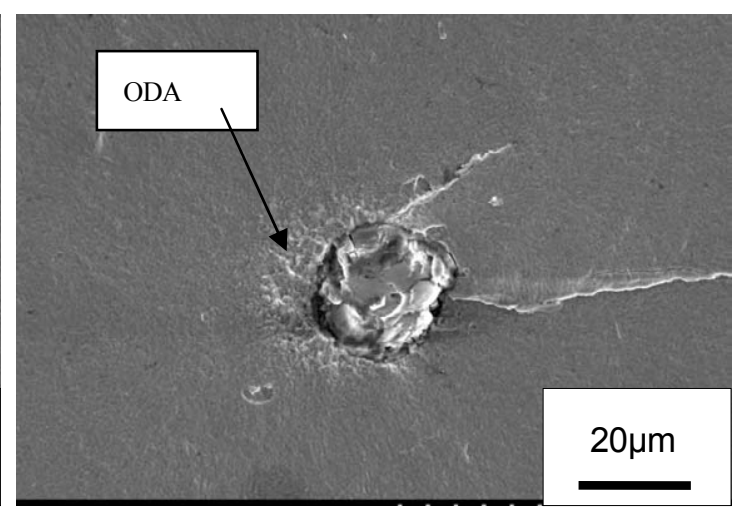

(b) The other side

Fig.4 Fractographs of a TF sample ended in fish-eye fracture. (Ultrasonic, $\sigma_{a}=800 \mathrm{MPa}, N_{\mathrm{f}}=7.20 \times 10^{8}$ cycles)

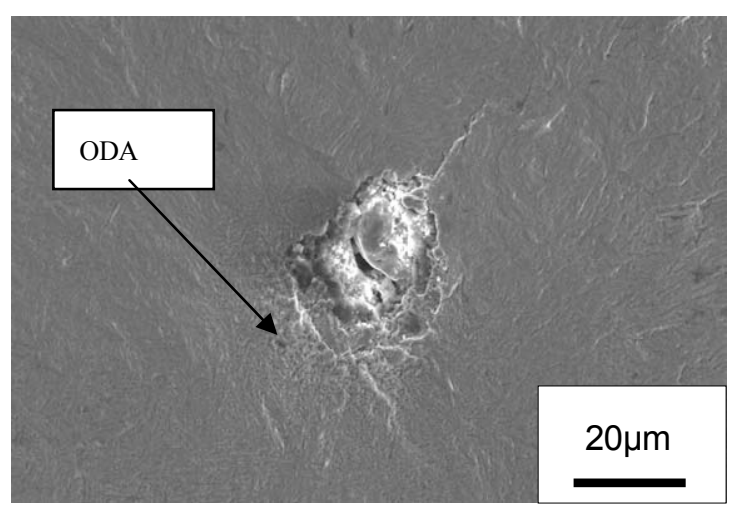

(a) One side

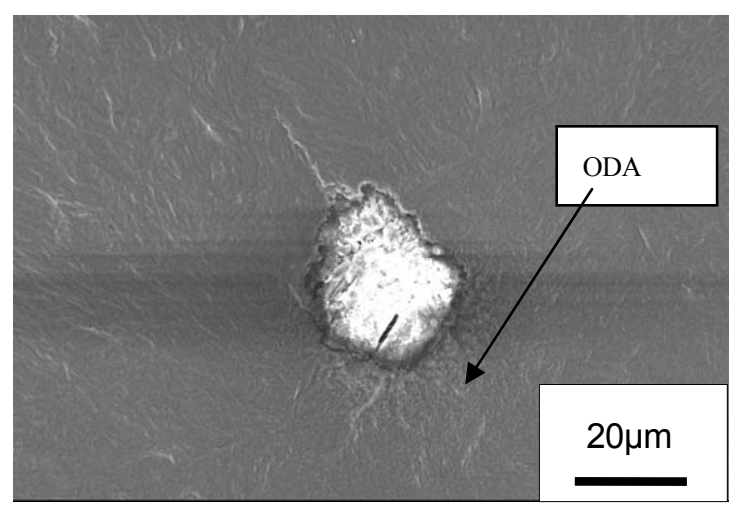

(b) The other side

Fig.5 Fractographs of a QT sample ended in fish-eye fracture. (Ultrasonic, $\sigma_{a}=850 \mathrm{MPa}, N_{\mathrm{f}}=1.65 \times 10^{8}$ cycles)

この破面には，介在物の周囲に凸凹した領域が観察されない。すなわち， $\mathrm{ODA}^{(5)}$ は認められない。これは破断繰 返し数が少ないためであり, ODA は $10^{7}$ 回以上で内部破壊した場合に明瞭となる傾向がある. 内部破壊した QT 材の他の 1 本の試験片の破面も同様の様相を呈し, 介在物の寸法も同程度であった. 図 4 と 5 に超音波疲労試験 で内部破壊した破面の起点付近の様相を示す。この場合もマッチング写真である. 図 4 は $\mathrm{TF}$ 材の $\sigma_{a}=800 \mathrm{MPa}$ で破断した試験片の破面様相であるが，起点は $24 \mu \mathrm{m} の$ 介在物であり，介在物は破面の両側に残っている．EDX 分析の結果, この介在物は $\mathrm{Al}, \mathrm{Si}, \mathrm{Mg}, \mathrm{Ca}$ が検出された. すなわち, 油圧サーボ試験の QT 材の内部破壊起点 と同じ介在物である。また，介在物の周囲には凸凹した領域が認められる．凸凹した領域は両側の破面でよく対 応しているため, これらは ODA と考えられる.この場合, ODA を含めた起点部の寸法は $31 \mu \mathrm{m}$ である. TF 材の 
$\sigma_{a}=825 \mathrm{MPa}$ で内部破壊した試験片も，起点部に同様の介在物が存在し，介在物周りに ODA が観察された．図 5 は QT 材の $\sigma_{a}=850 \mathrm{MPa}$ で破断した試験片の破面様相である. 起点となった介在物の寸法は $29 \mu \mathrm{m}$ 程度で，EDX 分析の結果，他の内部破壊起点の介在物と同じ成分であった。 また，介在物の周囲には ODA が認められた，QT 材の $\sigma_{a}=825 \mathrm{MPa}$ で内部破壊した試験片においても, 介在物と ODA が観察された. これらの結果から, 破面様 相についても TF 材と QT 材で特筆すべき違いは認められなかった.

以上のように，本研究では $\mathrm{TF}$ 材と QT 材はほぼ同等の疲労強度を示した。また，ODA の様相についても相違 は認められなかった．TF 材は強い $\alpha$ ファイバーを有する超微細繊維状フェライト粒組織を活用し， QT 材に比べ 降伏強度，全伸び，勒性，遅れ破壊特性を向上させた．特に，TF 材では層状破壊を活用することで勒性の著しい 向上が図られたが，一方ではその組織的特徵が疲労特性を低下させる懸念があった。しかし，実際には疲労強度 の低下は認められず，通常の焼戻しマルテンサイト鋼と同等の疲労強度を発揮した. 今後，様々な強度レベルに おける TF 材を作製し, 疲労特性について検討することが必要である.

\section{4. 結語}

本研究では $0.6 \% \mathrm{C}-2 \% \mathrm{Si}-1 \% \mathrm{Cr}$ 鋼の温間テンプフォーミング材について $10^{10}$ 回のギガサイクル疲労試験を実施 し，通常の焼戻しマルテンサイト材との比較を行った。得られた結果は以下のとおりである.

（1） TF 材と QT 材のいずれの材料も高応力・低寿命域では表面破壊，低応力・長寿命域では内部破壊となり， 疲労限は認められなかった。 また，いずれの材料も内部破壊の起点は酸化物系介在物であった.

（2） TF 材と QT 材はほぼ同等の疲労強度を示し，いずれの材料でも ODA が観察された. 従って，TF 材は通常 の QT 材と同様の疲労特性を示すことが明らかとなった.

\section{文献}

(1) Kimura, Y., Inoue, T., Yin, F., and Tsuzaki, K., "Delamination toughening of ultrafine grain structure steels processed through tempforming at elevated temperatures",Iron and Steel Institute of Japan(ISIJ) International, Vol.50, No.1(2010), pp.152-161.

(2) Inoue, T., Kimura, Y., and Ochiai, S., "Static fracture toughness of fail-safe steel”, Scripta MATERIALIA, Vol.65(2011), pp.552-555.

(3) Nie, Y., Kimura, Y., Inoue, T., Yin, F., Akiyama, E., and Tsuzaki, K., "Hydrogen embrittlement of 1500 MPa tensile strength level steel with an ultrafine elongated grain structure, Metallurgical and Materials Transactions A, Vol.43(2012), pp.1670-1687.

(4) Furuya, Y., Matsuoka, S., Abe, T. and Yamaguchi, K., "Gigacycle fatigue properties for high-strength low-alloy steel at 100 $\mathrm{Hz}, 600 \mathrm{~Hz}$, and $20 \mathrm{kHz}$ ", Scripta MATERIALIA, Vol.46(2002), pp.157-162.

(5) Murakami, Y., Nomoto, T. and Ueda, T.,"Factors influencing the mechanism of superlong fatigue failure in steels", Fatigue. Fracture Enginering Materials \& Structures, Vol.22(1999), pp.581-590. 